This item was submitted to Loughborough's Research Repository by the author.

Items in Figshare are protected by copyright, with all rights reserved, unless otherwise indicated.

\title{
Passion and pride in professional sports: Investigating the role of workplace emotion
}

\section{PLEASE CITE THE PUBLISHED VERSION}

http://dx.doi.org/10.1016/j.smr.2016.10.004

\section{PUBLISHER}

(C) Sport Management Association of Australia and New Zealand. Published by Elsevier

\section{VERSION}

AM (Accepted Manuscript)

\section{PUBLISHER STATEMENT}

This work is made available according to the conditions of the Creative Commons Attribution-NonCommercialNoDerivatives 4.0 International (CC BY-NC-ND 4.0) licence. Full details of this licence are available at: https://creativecommons.org/licenses/by-nc-nd/4.0/

\section{LICENCE}

CC BY-NC-ND 4.0

\section{REPOSITORY RECORD}

Swanson, Steve, and Aubrey Kent. 2019. "Passion and Pride in Professional Sports: Investigating the Role of Workplace Emotion”. figshare. https://hdl.handle.net/2134/23083. 


\section{PASSION AND PRIDE IN PROFESSIONAL SPORTS}

\section{Passion and Pride in Professional Sports:}

Investigating the Role of Workplace Emotion

10 The current study examined the influence of passion and pride on employees of professional

11 sport organizations. Anecdotally, much has been noted about the role that emotions play in 12 making the sport industry one of the world's largest and most visible. However, empirical 13 investigation is lacking in relation to those who choose a career in this environment. Results 14 from an analysis of 933 employee survey responses representing 89 teams across 5 leagues 15 suggest that passion and pride play an important role influencing commonly assessed workplace 16 attitudes and behaviors. Notably, obsessive passion seems to work in a distinctly positive fashion 17 within professional sport workplaces, as compared to its negative influence on employees within other non-sport industries researched previously. 


\section{Introduction}

Sport and emotion are inextricably linked (Vallerand, 1983; Vallerand \& Blanchard, 2000). For individuals in various roles (e.g., participant, coach, fan, etc.), emotion is at the core of the sporting experience (Duquin, 2000), and the passion that sport engenders is regarded as a distinguishing characteristic of the industry (Stewart \& Smith, 1999). Sport and emotion have been studied from multiple perspectives (e.g., sociological, psychological, and physiological) and in relation to numerous subjects such as pride, performance, culture, and fan experience (Duquin, 2000; Vallerand \& Blanchard, 2000). The sport management literature has also addressed the study of emotion, with this being primarily through the lens of consumer behavior and its association with fan-related attitudes and behaviors (e.g., Wann, Dolan, McGeorge, \& Allison, 1994).

Over the past decade there has been an increased emphasis in the mainstream management literature on the study of emotion in organizational life (e.g., Ashkanasy \& Daus, 2002; Barsade \& Gibson, 2007). The basis of this trend is that strong feelings are often present when individuals confront work issues related to organizational performance (Barsade \& Gibson, 2007), and that emotion (affect) plays an important role for key workplace attitudes and behaviors (Ashkanasy \& Daus, 2002). With the close association between sport and emotion, it seems plausible that emotion could also be an important element within the context of the sport workplace. While sport management has established a strong research paradigm for individuals external to organizations, enhanced focus is therefore needed on the role that emotion might play with regard to those working inside sport organizations (Todd \& Kent, 2009). For example, Taylor, Doherty, and McGraw (2008) suggest that the passion surrounding sport in general might also be reflected in employees working in the sport industry. They note examples of “...irrational 
passions and emotional attachments, despite the often variable quality of the product" (p. 2), and suggest that evidence provided from studies of job satisfaction and volunteering patterns may be indicative of a similar irrationality amongst the sport industry workforce. Todd and Harris (2009) suggest that the pride of sport employees can be a psychological benefit which leads to increased levels of satisfaction and performance. Their investigation of pride amongst employees of professional sport teams, and its impact on the development of organizational identification, suggests that this element of emotion may be similar to passion in its particular relevance to employees within sport.

With sport being so closely intertwined with the concept of emotion, the lack of attention given to its role in sport organizations is surprising. Other than Todd and Harris (2009), the study of pride and passion in the workplace is notably absent in the sport management literature. This study provides initial research to establish a baseline understanding of the role that these emotional constructs play in the sport workplace environment. Despite the fact that these emotional elements are often said to be distinguishing aspects of our field (e.g., Stewart \& Smith, 1999; Taylor et al., 2008), the current study makes one of the first attempts to explore these concepts empirically in relation to organizational behavior. As passion and pride are generally considered distinctly critical concepts in the sport context, it is proposed here that these constructs may also be particularly relevant for sport employees. The main purpose of the study is therefore to investigate the extent to which these affective constructs are linked to the organizationally relevant outcomes of commitment, satisfaction, involvement, and organizational citizenship behavior. For this initial investigation of emotion in the sport workplace, we included these specific outcomes due to their theoretical connection to passion and pride, their prevalence in the mainstream management literature (Schleicher, Hansen, \& Fox, 2011), and their specific 
relevance for employees working in the sporting environment (e.g., Doherty, 1998, Todd \& Kent, 2009).

\section{Theoretical Background}

\subsection{Overview of the Conceptual Model}

Our conceptual model of affective influence in the sport workplace is shown in Figure 1. The general premise for this model is based on previous management literature suggesting that constructs of emotion lead to organizationally relevant attitudes and behaviors (e.g., Ashkanasy \& Daus, 2002). More specifically this line of research suggests that positive emotions lead to positive outcomes, whereas emotions with a negative connotation are negatively related (or unrelated) to positive consequences (e.g., Ashkanasy \& Daus, 2002; Vallerand, 2010). As outlined above, the affective predictors chosen for the current study include both passion and pride. As will be outlined in more detail below, passion is conceptualized to have two distinct forms. Although not always the case, harmonious passion is primarily considered to be a 'good' or positive emotion, whilst obsessive passion is generally considered as more of a 'bad' or negative emotion (Vallerand, 2010). In the current study we also consider pride to be a positive affective construct due to its positive relationship with desirable outcomes in previous research (e.g., Todd \& Harris, 2009). We further propose that passion and pride will lead to both attitudinal and behavioral outcomes.

For our initial assessment of the influence of the affective constructs, we include established outcomes which are theoretically connected to the predictors. The attitudinal outcomes include organizational commitment, job satisfaction, and job involvement, which are three of the most highly researched attitudes in the employee literature and generally considered as desirable in the organizational setting (Schleicher, Hansen, \& Fox, 2011). With regard to 
behaviors, organizational citizenship behavior (OCB) is considered a key construct based on its important connection with organizational effectiveness, and is also one of the most heavily researched behaviors in the employee literature (Podsakoff, Whiting, Podsakoff, \& Blume, 2009). The list of outcomes also incorporates different conceptual foci (organization, job, and coworkers), which provides for a more comprehensive perspective on the influence of the affective predictors.

While the sport management literature has not given much attention to pride and passion in the workplace, there is some indication that constructs of emotion may be particularly relevant to the sport context. For example, Todd and Harris (2009) found the pride of sport employees to ultimately lead to job satisfaction, and theorized this in part to be related to the pleasurable state experienced when a job has high emotional significance to an employee. In addition, Swanson and Kent (2015) proposed that team identification would enhance positive attitudes like commitment and involvement for professional sport employees due to the meaningfulness they experience through this emotional connection with the team. Furthermore, the inclusion of these four outcomes is also consistent with Todd and Kent's (2009) proposition that they may be especially relevant for employees in the professional team sport environment. Consistent with findings noted above, the model indicates that harmonious passion and pride will have positive influence, while obsessive passion will be unrelated (or negatively related) to these organizationally relevant outcomes.

\section{--- INSERT FIGURE 1 ABOUT HERE ---}

\subsection{Passion}

The concept of passion has been considered by philosophers for more than three centuries. Multiple definitions have been proposed, however two generally accepted positions 

have emerged over time (Vallerand \& Houlfort, 2003; Vallerand et al., 2003; Vallerand, 2010). The first, espoused by Descartes (1596-1650), conceptualizes passion as a strong emotion which can be positive when reason serves as a basis for behavior (Vallerand et al., 2003). The second, proposed by Spinoza (1632-1677), is in concert with passion's etymology (from Latin passio meaning suffering) where passion can be negative because it is associated with a loss of reason and control (Vallerand, 2010).

Both of these perspectives are evident in the sporting environment. On one hand, it could be argued that passion has generally taken on a positive connotation in recent history, with a multitude of venerated descriptions of passionate athletes, coaches, and managers (e.g., Michael, 2008, Zinser, 2005), and success often considered to be at least in part the result of the passion one has for their sport (Vallerand et al., 2008a). That is, individuals who are passionate for their sport are able to dedicate themselves fully, and pursue their quest for excellence in the face of obstacles or resistance (Vallerand et al., 2008a). On the other hand, however, it should be noted that passion has also been cited in relation to unwise decisions in sport such as excessive sideline misconduct by coaches (e.g., BBC, 2010) and the use of expletives by senior managers communicating in the public domain (e.g., Mazzeo \& Youngmisuk, 2014).

Passion has also been considered as an important energy source for goal achievement, and is frequently viewed as a necessary ingredient for significant accomplishment (Vallerand et al. 2008a; Vallerand, 2010). Within the workplace specifically, passion (harmonious) has recently been associated with important outcomes such as engagement, commitment, and employee sense of control (Forest, Mageau, Sarrazin, \& Morin, 2011; Trepanier, Fernet, Austin, Forest, \& Vallerand, 2014). However, in relation to the divergent conceptualizations discussed above, passion (obsessive) has also been connected to negative consequences such as burnout 
139

140

141

142

143

144

145

and psychological conflict (Trepanier et al., 2014; Vallerand, 2010). In accordance with these differing relationships, a dualistic model of passion toward activities (such as work) has been developed (Vallerand \& Houlfort, 2003; Vallerand et al., 2003) which incorporates two distinct forms: harmonious and obsessive. This approach conceptualizes the general notion of passion as a strong feeling towards something which individuals like (or even love), find important, and invest their time and energy in (Vallerand et al., 2003; Vallerand, Paquet, Philippe, \& Charest, 2010). However, the specific form of passion is then distinguished by the process in which the focal object is internalized into an individual's self-concept (Vallerand et al., 2003), which can be either autonomous or controlled (Deci \& Ryan, 2000; Sheldon, 2002).

Harmonious passion refers to "a strong desire to freely engage" and is the result of autonomous internalization where individuals willingly accept the activity (or object) as important (Marsh et al., 2013, p. 797). This sense of willing participation is associated with volition and personal approval (Vallerand et al., 2010), where individuals freely engage in the activity rather than feeling compelled to do so (Vallerand et al., 2003). In contrast, obsessive passion refers to a "strong and uncontrollable urge to partake in the activity" (Belanger, Lafreniere, Vallerand, \& Kruglanski, 2012, p. 2), and is the result of controlled internalization where pressures are felt due to the perception of attached contingencies (Vallerand et al., 2010). In this situation individuals feel compelled to take part due to pressures such as social acceptance and self-esteem preservation, or because an uncontrollable sense of excitement is derived from engaging in the activity (Vallerand et al., 2003).

In concert with these dual conceptualizations of passion, research has generally shown harmonious passion to be associated with positive outcomes and obsessive passion to be linked to negative (or less positive) consequences (Forest et al., 2011). For example, the literature 
162

163

164

165

166

167

168

169

170

171

172

173

174

175

176

177

178

179

180

181

182

183

184

indicates that harmonious passion is positively associated with psychological well-being (Forest el al., 2011), self-esteem (Vallerand et al., 2008b), work engagement (Trepanier et al., 2014), and adaptive outcomes and positive emotions in general (Vallerand et al., 2003). Additionally, harmonious passion has been seen to be negatively associated with constructs such as burnout (Trepanier et al., 2014), shame (Vallerand et al., 2003), psychological distress (Forest et al., 2011), and intentions to quit (Burke, Astakhova, \& Hang, 2015). As for obsessive passion, previous studies have demonstrated a positive association with undesirable constructs such as burnout (Trepanier et al., 2014), conflict between work and life activities (Vallerand et al., 2010), and negative emotions in general (Vallerand et al., 2003). Previous research has also shown obsessive passion to have non-significant associations with positively viewed constructs such as self-esteem (Vallerand et al., 2008b), job performance (Burke et al., 2015), and positive emotions in general (Vallerand et al., 2003). In addition, some studies have indicated obsessive passion to have a negative relationship with adaptive outcomes such as psychological well-being and subjective vitality (e.g., Forest et al., 2011).

\subsection{Pride}

One of earliest references to the notion of pride is Aristotle's (384-322 BCE) conceptualization of it as a fundamental moral virtue (Sokolowski, 2001). From this perspective pride is a positive construct relating to dignity, self-efficacy, and feeling valuable as a person (Wärnå, Lindholm, \& Eriksson, 2007). This view is in line with the etymology of the word which stems from a variety of meanings such as having high opinion of oneself (prut: Old English), valiant (prud: Old French), and being of value (prudesse: Latin).

The concept of pride also has a close connection to the sporting environment. In relation to coaches and players, feelings of pride are generally viewed as being worthy of pursuit and 
185

experienced in conjunction with hard work and team success (e.g., Maraniss, 1999). For example, a common message in the sport psychology domain is that coaches should instill pride in their players to engender group cohesion which can ultimately contribute to team success (e.g., Weinberg \& Gould, 2011). Pride has also been identified as an important factor in the sport management literature. For example, civic pride has been viewed as an important benefit of hosting sporting events (e.g., Misener \& Mason, 2009), and national pride has been seen to play an important role in the development of national identity (Chalip, 2006). It has been suggested that volunteering at international sporting events can be viewed as an avenue for individuals to express their national pride (Bang \& Chelladurai, 2009), and that facilities can provide a tangible source for fans to experience the feeling of pride associated with sport (Wann, 2006). In sum, the concept of pride has been portrayed as the "cornerstone of fan consumption" and considered to be an antecedent of outcomes such as fan commitment, loyalty, and increased consumption (Decrop \& Derbaix, 2010, p. 586).

In the management and organizational behavior literature, the notion of pride has sometimes been viewed as an evaluation of the attitudinal target's status and general worth (e.g., Blader \& Tyler, 2009; Smith \& Tyler, 1997; Tyler \& Blader, 2001). While this approach has seemingly emphasized the cognitive aspects of the construct, in the current investigation we conceptualize pride more in line with recent studies which also account for its affective nature (e.g., Gouthier \& Rhein, 2011; Horberg, Kraus, \& Keltner, 2013). This approach does not cast pride as purely an affective construct, but instead is consistent with Smith and Tyler's (1997, p. 165) conceptualization of pride as a "measure of affective and evaluative feelings" about the attitudinal object. From this perspective we refer to pride in the workplace as feelings of 
importance, value, and admiration based on status evaluations of one's current job (Todd \& Harris, 2009; Tyler \& Blader, 2001).

Previous research indicates that pride is positively associated with a variety of outcomes generally considered as important in managerial settings and organizational research. For example, the literature suggests that pride leads to organizational identification for both employees (Todd \& Harris, 2009) and volunteers (Boezeman \& Ellemers, 2014), as well as affective organizational commitment for a wide range of employees working in different organizations and with various job types and levels (Ellemers, Kingma, van de Burgt, \& Barreto, 2011). It has also indicated that pride has a positive association with employee creativity

(Gouthier \& Rhein, 2011), self-efficacy (Todd \& Harris, 2009), job satisfaction, compliance, and intentions to stay (e.g., Tyler \& Blader, 2001). Indeed, pride in the workplace has been referred to as strategic asset which is closely linked with employee performance and business success more generally (Katzenbach, 2003a; 2003b). However, it has been suggested that many views noting the importance of pride are based more on anecdotes and intuition rather than empirical investigation (Gouthier \& Rhien, 2011).

\subsection{Theoretical Development}

2.4.1 Outcomes of passion. As the proposed outcomes in our model are considered as positive attitudes and behaviors in the workplace, the current research generally proposes their relationship to be positive with harmonious passion and nonsignificant (or negative) with obsessive passion (e.g., Philippe, Vallerand, Houlfort, Lavigne, \& Donahue, 2010; Vallerand et al., 2003; Vallerand, 2010).

Affective commitment is defined as "an individual's emotional attachment to and engagement in an employing organization" (Bedeian, 2007, p. 13). Relatively few studies have 
assessed the relationship between passion and commitment, however it seems intuitive that those who possess a strong desire to engage in their work (Marsh et al., 2013) would be more inclined to become emotionally attached and engaged with their organization (Bedeian, 2007). In addition, a positive relationship between harmonious passion and affective commitment would be consistent with Vallerand et al.'s (2003) finding of this passion type's connection with positive emotions in general. However, as previous research has indicated a nonsignificant relationship between obsessive passion and positive emotional outcomes (e.g., Vallerand et al., 2003; Vallerand et al., 2006), we propose a similar relationship with affective commitment. As obsessive passion is the result of controlled internalization and the experience of pressure (Vallerand et al., 2003), it seems likely that individuals will not be able to freely attach themselves emotionally to their employing organization. In addition, as Vallerand et al. (2003) indicates that this controlled internalization can originate from interpersonal pressure (e.g., coworkers), this stress could perhaps also lead to resentment or negative feelings about the organization. Such a finding would be consistent with previous research indicating lower levels of commitment for individuals who are obsessed with their work (Burke \& Fiksenbaum, 2009). Hypotheses 1a: Harmonious passion will be positively related to affective organizational commitment. Hypotheses 2a: Obsessive passion will be unrelated or negatively related to affective organizational commitment.

Job satisfaction refers to "a positive (or negative) evaluative judgment one makes about one's job or job situation" (Weiss, 2002, p. 175), with previous research indicating a positive relationship between harmonious passion and this form type of satisfaction (e.g., Carbonneau, Vallerand, Fernet, \& Guay, 2008; Vallerand et al., 2010). Vallerand et al. (2010) proposed this 
253

254

255

positive relationship to exist on the basis that harmonious passion allows individuals to experience task satisfaction through immersion in their work. This association is also based upon previous research indicating that it leads to a variety of adaptive outcomes such as work satisfaction (Carbonneau et al, 2008). In addition, since job satisfaction has been conceptualized as incorporating positive emotion (e.g., Lock, 1976), a positive relationship could also be expected due to harmonious passions generally leading to positive emotions both during and after the passionate activity (Burke et al., 2015; Vallerand et al., 2003). In line with previous research, however, we suggest that obsessive passion will be either unrelated or negatively related to work satisfaction (e.g., Burke et al., 2015; Carbonneau et al., 2008; Houlfort, Philippe, Vallerand, \& Ménard, 2014). This is proposed on the basis that the controlled internalization leads to more rigid forms of task engagement and constrains enjoyment associated with the activity (Burke et al., 2015; Vallerand \& Houlfort, 2003). This type of relationship would also be consistent with previous research where obsessed employees demonstrated lower levels of job satisfaction (Burke \& Fiksenbaum, 2009).

Hypotheses 1b: Harmonious passion will be positively related to job satisfaction. Hypotheses 2b: Obsessive passion will be unrelated or negatively related to job satisfaction.

\footnotetext{
The construct of job involvement refers to the degree of cognitive preoccupation and concern individuals have with their current job (Paullay, Alliger, \& Stone-Romero, 1994). Although we know of no passion research specifically assessing its relationship with job involvement, some studies have indicated a positive association with related constructs such as concentration (Forest et al., 2011; Vallerand et al., 2003), cognitive absorption, and attention (Ho, Wong, \& Lee, 2011). As these concepts both have overlap with cognitive engagement
} 
276

(Paullay et al., 1994), we also propose a positive relationship between harmonious passion and job involvement on the basis that autonomous internalization of work leads to employees to experience task engagement more fully (Vallerand et a., 2003). Another reason for this proposed positive relationship is that employees will be more likely to invest their attention to roles that they are passionate about (Ho et al., 2011). Conversely, we expect obsessive passion to be either unrelated or negatively related to job involvement. The general argument for this association is that pressured internalization leads to psychological conflict which distracts individuals from giving full attention to their jobs (Ho et al., 2011). A finding like this would also be consistent with previous research assessing the relationship between obsessive passion and attention, absorption, and concentration (Forest et al., 2011; Ho et al., 2011).

Hypotheses 1c: Harmonious passion will be positively related to job involvement. Hypotheses 2c: Obsessive passion will be unrelated or negatively related to job involvement.

Finally, organizational citizenship behaviors (OCBs) are those of a discretionary nature, which are not directly or explicitly recognized by a formal reward system, yet still promote the effective functioning of the organization (Ferrin, Dirks, \& Shah, 2006; Organ, 1988). Although, little attention has been given to the relationship between passion and OCBs, we propose a positive relationship on the basis that an intense desire to freely engage in one's work should lead to prosocial activity on behalf of the organization (Marsh et al., 2013). In addition, with OCBrelated concepts such as teamwork, cheerleading, and sportsmanship (Organ, 1988; 1990) being highly relevant in this environment, it seems that sports employees with harmonious desire would be naturally inclined to engage in behaviors directed more specifically to colleagues as well. However, as obsessive passion is generally associated with less adaptive (or maladaptive) 
outcomes (Vallerand et al., 2008a), we propose that obsessive passion will be unrelated or negatively related to OCBs. As obsessive passion is related to internal pressure and rigid persistence of tasks (Vallerand et al., 2003), this inflexibility may lead employees to view OCBs as distractions or even threats to their primary work (Burke et al., 2015). We therefore propose that harmonious and obsessive passion will also demonstrate contrasting relationships with discretionary behaviors which are beneficial to the organization.

Hypotheses $1 \mathrm{~d}$ : Harmonious passion will be positively related to organizational citizenship behavior.

Hypotheses 2d: Obsessive passion will be unrelated or negatively related to organizational citizenship behavior.

2.4.2 Outcomes of pride. As our conceptualization of pride is a general feeling of importance and value based on the status on one's job, we expect this construct to relate positively with the organizationally desirable outcomes included in this investigation. Whilst this construct has not received a great deal of attention in the literature (Gouthier \& Rhein, 2011), previous studies have indicated positive relationships with a variety of important workplace outcomes (e.g., Todd \& Harris, 2009; Tyler \& Blader, 2001). In the current research, we first propose that pride in the workplace will be positively associated with employee levels of affective organizational commitment. As employees experience positive emotion from perceptions of job importance and status, we propose that these individuals will attribute some of this feeling to their employing organization and in turn become more emotionally attached (e.g., Bedeian, 2007). Relatively few studies have assessed the association between pride and commitment in the workplace, however some empirical support does exists for a positive 
relationship between affective commitment and both group pride (Tyler \& Blader, 2001) and organizational pride (Ellemers et al., 2011). We therefore propose the following hypothesis. Hypotheses 3a: Pride in one's job will be positively related to affective organizational commitment.

We also propose that pride will be positively related to employee job satisfaction in this setting. As individuals experience positive feelings from perceptions of their job's status and importance, it seems likely that this will lead to positive evaluations and feelings about their job or job situation (Locke, 1976; Weiss, 2002). The literature also provides empirical support for this proposition, with pride demonstrating a positive influence on work satisfaction (Ellemers et al., 2011), as well as satisfaction with one's job and supervisor (Tyler \& Blader, 2001). Hypotheses 3b: Pride in one's job will be positively related to job satisfaction. A similar relationship is also proposed between pride and job involvement. We know of no research specifically assessing this relationship; however we suggest that feelings related to perceived job importance and value will lead to increased levels of cognitive preoccupation and concern for one's job, along the lines of Paullay et al. (1994). That is, the more employees experience positive emotion in relation to job status, the more focused they will become to deliver on expectations and maintain their occupational standing.

Hypotheses 3c: Pride in one's job will be positively related to job involvement.

Finally, we suggest that pride in one's job will lead to prosocial behaviors beyond employees' contractual obligations. For example, employees who experience positive feelings from perceptions of job importance and value may also be more likely to assist coworkers as an additional means of feeling important and valued. In addition to its relationship with the 
aforementioned attitudinal outcomes, we propose pride to be an important affective construct which also leads to positive employee behaviors in professional sport organizations. Hypotheses 3d: Pride in one's job will be positively related to organizational citizenship behaviors.

\section{Methodology}

\subsection{Sample and Measures}

The participants were business operations employees from 89 randomly sampled organizations in the top five professional sports leagues in North America: Major League Baseball (MLB, 19), Major League Soccer (MLS, 12), the National Basketball Association (NBA, 19), the National Football League (NFL, 20), and the National Hockey League (NHL, 19). These individuals worked in departments such as communications, public relations, marketing, sales, accounting, finance, human resources, facilities, and information technology. Using proportional stratified sampling method (e.g., Leedy \& Ormrod, 2001), approximately $63 \%$ of the teams in each league were randomly chosen for the study with data collected via online surveys sent to 8,739 employees. A total of 933 participants completed the survey for a response rate of $10.7 \%$. The participants were $66.3 \%$ male, $83.8 \%$ Caucasian, with the average age and organizational tenure being 35.9 years and 6.0 years, respectively. In terms of league representation, $33.9 \%$ of the sample was from MLB, $21.3 \%$ from the NBA, $19.7 \%$ from the NHL, $19.0 \%$ from the NFL, and $6.1 \%$ from MLS.

The current study used survey items which have been used previously in the literature and shown to be valid and reliable. Each scale used a five-point Likert-type scale unless otherwise indicated $(1=$ strongly disagree and $5=$ strongly agree). Harmonious and obsessive passion were each measured with three items from Vallerand et al.'s (2003) passion for work 
scale, per Trepanier et al. (2014). Job pride was assessed using the three-item scale developed by

Todd and Harris (2009). To measure affective organizational commitment, we utilized Meyer,

Allen, and Smith's (1993) six-item affective commitment scale, and job satisfaction was assessed with Cammann, Fichman, Jennkins, and Klesh's (1983) three-item measure. Following Frone, Russell, and Cooper (1995), job involvement was measured using the five-item abbreviated version of Kanungo's (1982) job involvement scale with items assessed on a six-point Likerttype scale $(1=$ strongly disagree; 6 = strongly agree). Finally, organizational citizenship behavior was assessed using three-items from Lee and Allen's (2002) measure for citizenship behaviors

374 towards coworkers.

\subsection{Data Analysis and Results}

3.2.1 Non-response and common methods. Non-response error is concerned with

377 whether respondents can be seen as true representatives of the entire sample, and the assessment 378 of differences between respondents and non-respondents (Dillman, Smyth, \& Christian, 2009;

379 Jordan, Walker, Kent, \& Inoue, 2011). In order to assess the potential for non-response error, a 380 short follow-up survey was sent to approximately 2,500 non-participants from the original 381 survey. This included two demographic variables (age and gender), and one item from four 382 different constructs in the original survey. The 101 respondents were then compared to original 383 survey respondents across the six variables. The results of a chi-square test $(p=.32)$ indicated 384 that responders and non-responders did not differ with respect to gender, and MANOVA results 385 indicated no differences amongst the other variables $\left(\right.$ Wilks' $\left.^{\prime} \Lambda=.99, F(5,1028)=1.59, \mathrm{p}=.16\right)$. 386 These results suggest a reduced concern of nonresponse error for the current study.

387 Common methods bias refers to an element of measurement error that can be attributed to 388 the method used in a particular study (Podsakoff, MacKenzie, Lee, \& Podsakoff, 2003). As a 
first indication, Harman's one-factor test was conducted by performing a principle component analysis with all items in the study (e.g., Stam \& Elfring, 2008). Six distinct factors were extracted explaining $67 \%$ of the total variance, with the first factor accounting for $33 \%$. With no single factor emerging, nor one which accounted for a majority of the explained variance, these results lessen the concern regarding common method variance in the current study (Stam \& Elfring, 2008). As a second test, a single item marker variable of agreeableness was also included, as marker variables are theoretically not related to any other variables in the study (Podsakoff et al., 2003). Other than a small negative association with affective commitment (-.08) and job satisfaction (-.13), the marker variable was not significantly correlated with any of the other constructs in the current study $(\mathrm{p}<.05)$. The collective results suggest that common method variance is not of great concern in the current research (Pritchard \& Funk, 2010).

3.2.2 Measurement model analysis. The data was analyzed in a two stage structural equation modeling (SEM) process (Anderson \& Gerbing, 1988). First, a measurement model was assessed using confirmatory factor analysis (CFA) which specified all of the survey items loading on their respective latent constructs. As there were some items with non-normal distributions, all SEM analysis utilized maximum likelihood estimation with robust standard errors (MLR), which addresses the potential violation of multivariate normality in such circumstances (Muthén \& Muthén, 1998-2012). To assess the convergent validity of the seven constructs, we assessed both the construct reliability (CR) and average variance extracted (AVE) levels as outlined by Fornell and Larcker (1981). All the constructs had CR and AVE levels above .7 and .5 , respectively, with only one exception. Contrary to previous findings, harmonious passion indicated inadequate convergent validity $(\mathrm{CR}=.64 ; \mathrm{AVE}=.38)$ and was therefore removed from the analysis (Fornell \& Larcker, 1981). Another measurement model 
412 was then assessed which specified the remaining six constructs and their associated items. All

413 factor loadings were significant and above the recommend .5 level (Hair, Black, Babin,

414 Anderson, \& Tatham, 2006; Hulland, 1999), and the CFA indicated acceptable fit with the data

$415(\chi 2=842, d f=215, \mathrm{CFI}=.93, \mathrm{TLI}=.92, \mathrm{RMSEA}=.06, \mathrm{SRMR}=.05)$. With only one exception

416 (AVE=.49 for affective commitment), all the latent constructs met the recommended levels of

417 CR and AVE (Fornell \& Larcker, 181). As AVE is a conservative measure which is often

418 slightly below .5 (Jiang, Klein, \& Carr, 2002), this lone exception was deemed acceptable for the

419 current analysis. The CR, AVE, and Cronbach alpha values for the constructs are provided with

420 the correlation matrix in Table 1.

\section{--- INSERT TABLE 1 ABOUT HERE ---}

Discriminant validity was also assessed by comparing the squared interconstruct correlation (SIC) values with the AVE value for each construct (Fornell \& Larcker, 1981). In all but the following two cases, the AVE was greater than the SIC values between relevant construct pairs: obsessive passion and job involvement; and, affective commitment and job satisfaction. Following Anderson and Gerbing (1988), chi-square difference tests were then conducted which compared the measurement model with two alternate models that constrained the relationship between each of these construct pairs to be equal to 1.0 (Anderson \& Gerbing, 1988). As appropriate with MLR estimation, all SEM procedures of this nature utilized the Satorra-Bentler scaled chi-square difference test (Muthén \& Muthén, 1998-2012). In both cases, the results

431 indicated that the constrained model has significantly worse fit with the data than the 432 unconstrained measurement model: obsessive passion and job involvement $\left(\Delta \chi 2_{(I)}=118, \mathrm{p}<\right.$ $433.001)$; and, affective commitment and job satisfaction $\left(\Delta \chi 2_{(I)}=262, \mathrm{p}<.001\right)$. In addition to this 434 analysis providing support for discriminant validity, this is generally not viewed as a concern 
435

436

437

438

439

440

441

442

443

444

when correlation levels are below the .85 level (Kline, 2005). These results lessened the concern for discriminant validity issues, and the measure model was retained for use in the structural model analysis.

3.2.3 Structural model analysis. The structural model was assessed while accounting for whether the respective leagues were currently in season. Due to the possibility that employees could be more passionate and prideful about their jobs, and more committed and cognitively involved when their teams are actively competing, a dummy variable for this aspect (in-season 1; off-season 0) was also included. Consistent with the measurement model, the results of the hypothesized structural model also indicated acceptable fit with the data $\left(\chi^{2}=870, d f=234\right.$, CFI $=.93, \mathrm{TLI}=.92, \mathrm{RMSEA}=.05, \mathrm{SRMR}=.04, \mathrm{AIC}=55868)$. After determining acceptable fit for the hypothesized model (Model 1), two alternative models were also considered (see Table 2). The first comparison (Model 2) assessed Vallerand et al.'s (2008b) proposition that in certain situations passion may be an antecedent of the pride construct. Model 2 therefore specified obsessive passion leading directly to job pride, which in turn predicted all of the remaining constructs. However, as results from this model indicated worse fit with the data for all of the model fit indices $(\chi 2=979, \mathrm{df}=257, \mathrm{CFI}=.92, \mathrm{TLI}=.91, \mathrm{RMSEA}=.06, \mathrm{SRMR}=.05, \mathrm{AIC}=$ 61857), Model 1 was retained. The second comparison assessed the potential for organizational citizenship behavior being more distal from the effects of passion and pride, and stemming directly from the attitudinal variables of commitment, satisfaction, and involvement (e.g., Organ \& Ryan, 1995; Rich, Lepine, \& Crawford. 2010). Model 3 therefore specified obsessive passion and job pride both predicting affective commitment, job satisfaction, and job involvement, which in turn all predicted organizational citizenship behavior. However, as the results from this analysis also indicated worse fit with the data $(\chi 2=1419, d f=263, \mathrm{CFI}=.88, \mathrm{TLI}=.86$, 
$\mathrm{RMSEA}=.07, \mathrm{SRMR}=.09, \mathrm{AIC}=62341)$, Model 1 was therefore retained as the final structural model. Figure 2 displays the results of the final structural model with the standardized path coefficients listed next to each of the hypothesized relationship paths. Contrary to expectations, all of the hypothesized relationships between obsessive passion and the outcomes (H2a-d) indicated a significant positive association rather than a nonsignificant or negative relationship. However, the results did support the hypothesized positive relationships between job pride and all of the specified outcomes in the model (H3a-d).

\section{--- INSERT TABLE 2 ABOUT HERE ---}

\section{--- INSERT FIGURE 2 ABOUT HERE ---}

\section{Discussion}

This study sought to investigate the extent to which passion and pride are associated with key employee outcomes in the professional sport environment. The results of the structural equation modeling analysis indicate that both passion and pride are significantly related to affective organizational commitment, job satisfaction, job involvement, and organizational citizenship behaviors. However, the most notable finding of the current investigation is that obsessive passion had a positive relationship with these outcomes, as previous research has generally shown this construct to be unrelated (or negatively related) to positive consequences in the workplace (e.g., Ho et al., 2011; Forest et al., 2011; Trepanier et al., 2014).

As the literature suggests that passion is the result of how an activity is internalized into the self-concept (Vallerand et al., 2003), one explanation for the current findings is that passion is somehow internalized in a different manner within the professional sport setting. The dualistic approach outlined above proposes that a passion which is internalized though free acceptance and without perceived contingencies (i.e., harmonious) will in turn lead to positive outcomes. 
481

482

483

484

485

486

487

488

489

490

491

492

493

494

495

496

497

498

499

500

501

502

503

Therefore, rather than perceiving interpersonal or intrapersonal expectations as a contingency, obsessive passion in the present context might instead be internalized in an autonomous fashion. That is, the "strong and uncontrollable urge" (Belanger et al., 2012, p. 2) to take part in work activities may be more freely accepted by employees working in the sport environment. One explanation could be that the team environment of the current study might facilitate free acceptance of interpersonal pressures, as reliance on others is a standard aspect of team dynamics. For example, it could be that many sport employees have sporting backgrounds that have conditioned them to view pressure from their work teams as standard operating procedure, or perhaps even something that they welcome in relation to an interest and background in competitive sport. Future research should therefore focus on the specific sporting backgrounds of employees as one possible explanation for obsessive employee passion having a positive influence in this setting.

The manner in which work activity is internalized could also be related to sport employees having irrational perspectives (Taylor et al., 2008) and high levels of attraction to the industry (Todd \& Kent, 2009). For example, an elevated attraction toward working in professional sport could in turn manifest into more freely accepting an impulse to partake in work activities (e.g., Belanger et al., 2012). In a similar way, it could be that motivations found in the sport volunteer literature such as sharing contextual expertise (Allen \& Shaw, 2009; Fairley, Kellett, \& Green, 2007) and sharing a connection to the sporting events and the overall mission itself (Filo, Funk, \& O'Brien, 2009), may also play a role for those who have jobs in the sport industry. Future qualitative inquiry might play a pivotal role in identifying reasons why a sense of volition and personal approval (e.g.,Vallerand et al., 2010) may be operating in place of the controlled internalization normally associated with obsessive passion. 
The sport component of the present environment provides another possible explanation for obsessive passion's positive influence. Whilst this construct is generally not associated with positive outcomes, one exception to this trend is in the context of sport participation. Recognizing that passionate athletes often excel in their chosen sports, Vallerand et al. (2008a) proposed that dedication (e.g., practice) may play a significant role in linking obsessive passion to performance level. Deliberate practice refers to engagement in highly structured activities with the clear goal of improving on related tasks, and previous research in various domains has indicated its significant influence on performance (Vallerand, 2010; Vallerand et al., 2008a). In two studies utilizing basketball, water polo, and synchronized swimming participants, Vallerand et al. (2008a) found obsessive sport passion to have a positive influence on deliberate practice, which in turn led to higher levels of performance approach, mastery goals, and performance attainment. As the professional sport context is saturated with participation examples and highlevel performance, this atmosphere may be more conducive to positive outcomes from obsessive passion. With a constant focus on team performance, it's possible that a sports participation mindset is present in this particular workplace environment which enables positive outcomes for obsessively passionate employees.

Viewing sport employee mentalities in this way, it could be that an obsessive mentality towards work may be a normative component of the organizational cultures and internalized more freely in this setting. An uncontrollable sense of excitement may be derived from working in this atmosphere, but internalized autonomously and welcomed by those who are can strongly relate to sports participation. As the primary objective of these organizations is to enable success in the competitive arena, employees may readily accept associated pressures as a normative 
aspect of the environment. Future research should investigate this mentality more fully, and also consider the role of deliberate practice in this process.

The concepts which are reflected in the obsessive passion survey items may also be instructive when considering this positive influence further. These questions relate to employees being emotionally reliant on their jobs, experiencing obsessive feelings about work, and having difficulty imagining life without their current occupation. The notion that emotional significance can serve as a positive force is consistent with Todd and Kent's (2009) research on social identity and sport employees. Underscoring the emotional significance attached to membership in high profile status groups (e.g., Tajfel, 1981), these authors proposed that working in sport can engender psychological fulfillment which leads to organizationally relevant attitudes and behaviors. As they referred to this concept as a positive social identity derived from increased levels of member attraction (Todd \& Kent, 2009), a desire to be part of the sport industry might also be associated with unbridled excitement and compelling urges to work in this setting (i.e., obsessive passion) (Vallerand et al., 2003). In addition, the knowledge of belonging to a high profile social group (e.g., professional sport) could indeed become part of an individual's selfconcept (e.g., Tajfel, 1981) and therefore make it more difficult to imagine working in a different environment. The relationship between passion and social identity is worthy of further exploration, and the connection between these concepts provides additional perspective on how obsessive passion can have a positive influence in this setting. The influence of the predictor variables ranged from small to large in effect size (Cohen, 1988) with r-squared values indicating between eight and sixty-four percent of variance explained in the outcomes (see Figure 2). Of particular note was the strong positive effect of obsessive passion on job involvement, as this construct is not generally found to be associated 
with task-related concentration (Vallerand, 2010). One basis for obsessive passion being nonconducive to cognitive performance is because ego-invested processes are also involved (Hodgins \& Knee, 2002; Vallerand, 2010). Individuals are unable to concentrate due to distracting external factors such as the outcomes and other participants, which only allows for partial investment on the task at hand (Vallerand, 2010). One explanation for obsessive passion being supportive of job involvement in the present case is that a team-focused environment might meld these factors more closely together. With a focus on team outcomes being predominant in this setting, it could be that outcomes related to specific tasks seem less of distraction and simply in line with the main objectives of the organization. Furthermore, a large emphasis on teamwork might also assist in participant cohesion in this environment. Such a factor might therefore lead employees to see other task participants as less of a distraction and more as a useful cog in the overall process. With job involvement's close connection to individual performance and organizational effectiveness (Diefendorff, Brown, Kamin, \& Lord, 2002; Lawler, 1992), subsequent research should examine the potential for obsessive passion to play such a significant positive role in other sport settings. As professional sports teams represent only a fraction of the sports industry as a whole, additional inquiry should address this relationship within a variety of other sectors (e.g., manufacturing, and non-profit organizations). Finally, obsessive passion's relative impact on the outcomes should also be considered. While interpreting the results it should first be noted that some of the positive influence of obsessive passion could in part be due to variance shared with harmonious passion. Future research should therefore look to test the potential for such a circumstance when considering the relative influence of each passion construct. Although the directionality of obsessive passion's influence was indeed a surprise, its magnitude of effect in comparison with pride was also 
unexpected. Obsessive passion had a larger effect on all of the attitudinal outcomes, with job pride having the greater influence on OCBs only. When comparing meanings between the two predictor variables, it may be that the interpersonal aspects of job pride (i.e., value and admiration) are more relevant for promoting prosocial activities on behalf of the organization (e.g., Marsh et al., 2013). Nevertheless, with pride being a more established predictor of key outcomes such as satisfaction, self-efficacy, and commitment (e.g., Ellemers et al., 2011; Todd \& Harris, 2009; Tyler \& Blader, 2001) in the mainstream literature, obsessive passion's significant influence in the professional sport setting whilst accounting for job pride is notable.

\section{Limitations, future directions, and concluding comments}

As directions for future research are considered, limitations of the current study should also be noted. The cross-sectional design of present research does not account for any differences in data which may occur over time, nor does it allow for conclusions to be made regarding causality. Future studies should therefore consider multiple data collection points to address this issue, especially as these might identify any nuances due to the seasonality of professional sport. As customary in the literature, the measurement model and structural model were also analyzed using the same sample. Whilst the current data had representation across five major sports leagues, cross-validation with alternative samples from various geographical regions is also recommended for future research. In addition, a major limitation to the current investigation is that the abbreviated harmonious passion scale did not satisfy the statistical criteria necessary for inclusion in the structural equation analysis. Use of the extended passion scale is therefore recommended for future studies to potentially mitigate this circumstance, and provide increased understanding of how the dualistic model of passion operates within the sport workplace environment. 
Based on the present findings, future employee studies should also consider the sport

596

597

598

599

600

601

602

603

604

605

606

607

608

609

610

611

612

613

614

615

616 participation literature for constructs associated with the development of passion and pride. For example, Vallerand et al. (2006) found the value participants place on their respective sports to be a strong predictor of both obsessive and harmonious passion. Subsequent research may wish to consider previous work in the sport management literature incorporating sport-specific attitudes (e.g., Trail, Robinson, Dick, \& Gillentine, 2003) and investigate how passion towards sport in general may also play a role in this process. Utilizing the internalization framework of the dual model of passion, Vallerand et al. (2006) also found evidence for personality orientation (autonomous and controlled) being predictive for both forms of passion. Future employee research may therefore contemplate how other personal characteristics such as background and experience (e.g., Swanson \& Kent, 2014) might play a role in this process.

Other factors in the sport context previously viewed as antecedents of pride such as industry prestige (e.g., Todd \& Harris, 2009) and team success (e.g., Decrop \& Derbaix, 2010) should also be considered for future research in this area. In addition, future studies may wish to consider how sport related concepts such as "basking in reflective glory" (BIRGing) (Cialdini et al., 1976, p. 366) and team identification (Wann, 1997) might be related to passion and pride for professional sport employees. For example, while the current sample included employees working for organizations with both successful and unsuccessful sports teams, a perceived association with the celebrity participants might still serve as a catalyst for increasing employee levels of passion and pride. Fandom in the workplace (e.g., Swanson \& Kent, 2015), where sport employees can identify with their organization's affiliated sports teams, might also be a factor in relation to how passionate and prideful employees are about their work. 
While the current investigation conceptualized and measured pride as a unidimensional construct (e.g., Boezman \& Ellemers, 2007; Boons, Stam, \& Barkema, 2015; Smith and Tyler, 1997) as is a common approach in the literature, it is also worth noting that other scholars have viewed pride from a multidimensional perspective. For example, Tracy and Robbins (2007) view the concept of pride to consist of two different types; authentic and hubristic. According to the authors, authentic pride is associated with accomplishment and confidence, whereas hubristic pride has a narcissistic element relating to arrogance. Future research on employee pride in the sport industry should therefore look to also consider the role that these more specific types of passion might also pay in the sport environment.

As the current study incorporated only positive outcomes, additional research is needed which considers the potential for negative outcomes of passion and pride. Despite the positive effects found in this research, the literature generally indicates that obsessive passion is related to negative outcomes such as rigid persistence, burnout, and life conflict which might be especially relevant in the sport environment (Vallerand, 2010). For example, Vallerand et al. (2008b) found that obsessive passion in sports fans to be predictive of negative consequences such as hate towards opponents, mocking the supporters from rival teams, and partner relationships conflict. The stream of research relating to work-family conflict in sport (e.g., Dixon \& Bruening, 2007) may be especially relevant to consider in terms of its relationship with obsessive passion in the workplace. As pride has also been associated with organizational failure and antisocial behavior 636 when conceptualized in relation to narcissism (e.g., Bodolica \& Spraggon, 2011), additional 637 consideration is also warranted for negative outcomes of this construct as well. When considering the positivity indicated in the current study, attention should also be given to employee levels of obsessive passion. Rather than obsessive passion being more 
positive in the sport workplace setting then elsewhere, it could instead be that the threshold for creating negative outcomes is simply pushed further along the continuum. Obsessive passion could therefore also have a nonsignificant (or negative) relationship with positive outcomes in the sport workplace that does not manifest until the level exceeds a certain threshold. That is, while being passionate about one's craft could be a normative aspect of high achievement levels in sport, it may not be until sport employees become excessively passionate about their work that negative consequences materialize. Similar consideration is also needed in relation to job pride, as it could be that going beyond an optimal range will instead lead to negative outcomes. Employees who feel unrealistically important or overly preoccupied with their own status could

649 in turn become unconducive for teamwork and organizational performance objectives. For 650 individuals operating at a below-optimal level of obsessive passion, however, one potential 651 implication would be for managers in this setting to emphasize the exciting and self-esteem 652 enhancing aspects (e.g., Vallerand et al., 2003) of employment, which could in turn enhance the cognitive involvement levels of these individuals. Future research is therefore needed to look at how passion and pride levels may impact organizational outcomes across different work settings.

655 It should also be considered whether organizations would be better off targeting passionate and 656 prideful individuals in their recruiting efforts, or instead focus on augmenting these emotional 657 factors through human resource initiatives after employment. Additional managerial implications 658 include determining an appropriate balance between focusing on normal dispassionate business 659 objectives versus leveraging the emotional aspects that sport can offer. Finally, the results of the current study provide support for Todd and Kent's (2009)

661 proposition that the sport industry contains areas of distinction in relation to employee 662 psychology. While the literature generally indicates that individuals who are obsessively 
663 passionate about an activity "cheat themselves out of some important positive outcomes"

664 (Vallerand, 2010, p. 182), the findings here suggest this not to be the case for key organizational 665 outcomes in the sport workplace. These findings provide the first empirical evidence that passion 666 and pride play significant roles in fostering sport employee commitment and satisfaction, 667 cognitive involvement, and voluntary behaviors which are beneficial to the organization (e.g., 668 Todd \& Kent, 2009). Managers should therefore look to incorporate passion and pride building 669 capacity into their organizational objectives, as these integral components of sport participation 670 also appear useful for individuals working in sport. As sport management scholars have noted 671 the importance of establishing distinct aspects of our discipline (e.g., Chalip, 2006; Slack, 1996), 672 the role of emotion in the sport workplace represents another productive avenue toward realizing 673 this potential. 
674

675

676

677

678

679

680

681

682

683

684

685

686

687

688

689

690

691

692

693

694

695

\section{References}

Allen, J. B., \& Shaw, S. (2009). "Everyone rolls up their sleeves and mucks in": Exploring volunteers' motivation and experiences of the motivational climate of a sporting event. Sport Management Review, 12(2), 79-90.

Anderson, J. C., \& Gerbing, D. W. (1988). Structural equation modeling in practice: A review and recommended two-step approach. Psychological Bulletin, 103(3), 411-423.

Ashkanasy, N. M., \& Daus, C. S. (2002). Emotion in the workplace: the new challenge for managers. Academy of Management Executive, 16(1), 76-86.

Bang, H., \& Chelladurai, P. (2009). Development and validation of the volunteer motivations scale for international sporting events (VMS-ISE). International Journal of Sport Management and Marketing, 6(4), 332-350.

Barsade, S. G., \& Gibson, D. E. (2007). Why does affect matter in organizations? Academy of Management Perspectives, 21(1), 36-59.

BBC. (2010, November 15). Neil Lennon to answer 'excessive misconduct' charge. BBC Sport. Retrieved August 4, 2015, from http://http://news.bbc.co.uk/sport1/hi/football/teams/c/celtic/9189791.stm

Bedeian, A. G. (2007). Even if the tower is "ivory," it isn't “white:” Understanding the consequences of faculty cynicism. Academy of Management Learning \& Education, 6(1), 9-32.

Belanger, J. J., Lafreniere, M. K., Vallerand, R. J., \& Kruglanski, A. W. (2012). When passion makes the heart grow colder: the role of passion in alternative goal suppression. Journal of Personality and Social Psychology, 104(1), 1-22. 
696

697

698

699

700

701

702

703

704

705

706

707

708

709

710

711

712

713

714

715

716

717

718

Blader, S. L., \& Tyler, T. R. (2009). Testing and extending the group engagement model: linkages between social identity, procedural justice, economic outcomes, and extrarole behavior. Journal of Applied Psychology, 94(2), 445-464.

Bodolica, V., \& Spraggon, M. (2011). Behavioral governance and self-conscious emotions: Unveiling governance implications of authentic and hubristic pride. Journal of Business Ethics, 100(3), 535-550.

Boezeman, E. J., \& Ellemers, N. (2014). Volunteer leadership: the role of pride and respect in organizational identification and leadership satisfaction. Leadership, 10(2), 160-173.

Boons, M., Stam, D., \& Barkema, H. G. (2015). Feelings of pride and respect as drivers of ongoing member activity on crowdsourcing platforms. Journal of Management Studies, $52(6), 717-741$.

Burke, R. J., Astakhova, M. N., \& Hang, H. (2015). Work passion through the lens of culture: Harmonious work passion, obsessive work passion, and work outcomes in Russia and China. Journal of Business and Psychology, 30(3), 457-471.

Burke, R. J., \& Fiksenbaum, L. (2009). Work motivations, work outcomes, and health: Passion versus addiction. Journal of Business Ethics, 84(2), 257-263.

Cammann, C., Fichman, M., Jenkins, G. D., Jr., \& Klesh, J. R. (1983). Assessing the attitudes and perceptions of organizational members. In S. E. Seashore, E. E. Lawler, P. H. Mirvis, \& C. Cammann (Eds.), Assessing organizational change: A guide to methods, measures, and practices (pp. 71-138). New York, NY: Wiley.

Carbonneau, N., Vallerand, R. J., Fernet, C., \& Guay, F. (2008). The role of passion for teaching in intrapersonal and interpersonal outcomes. Journal of Educational Psychology, 100(4), 977-987. 
Chalip, L. (2006). Toward a distinctive sport management discipline. Journal of Sport Management, 20, 1-21.

Cialdini, R. B., Borden, R. J., Thorne, A., Walker, M. R., Freeeman, S., \& Sloan, L. R. (1976). Basking in reflected glory: Three (football) field studies. Journal of Personality aid Social Psychology, 34(3), 366-375.

Cohen, J. (1988). Statistical power analysis for the behavioral sciences (2nd ed.). Hillsdale, NJ: Lawrence Erlbaum.

Deci, E. L., \& Ryan, R. M. (2000). The "what" and "why" of goal pursuits: Human needs and the self-determination of behavior. Psychological Inquiry, 11(4), 227-268.

Decrop, A., \& Derbaix, C. (2010). Pride in contemporary sport consumption: a marketing perspective. Journal of the Academy of Marketing Science, 38(5), 586-603.

Diefendorff, J. M., Brown, D. J., Kamin, A. M., \& Lord, R. G. (2002). Examining the roles of job involvement and work centrality in predicting organizational citizenship behaviors and job performance. Journal of Organizational Behavior, 23(1), 93-108.

Dillman, D. A., Smyth, J. D., \& Christian, L. M. (2009). Internet, mail, and mixed-mode surveys: the tailored design method (3rd ed.). Hoboken, NJ: John Wiley \& Sons.

Dixon, M., \& Bruening, J. (2007). Work-family conflict in coaching: A top-down perspective. Journal of Sport Management, 21(3), 377-406.

Doherty, A. J. (1998). Managing our human resources: A review of organisational behaviour in sport. Sport Management Review, 1(1), 1-24.

Duquin, M. (2000). Sport and emotions. In J. Coakley \& E. Dunning (Eds.), Handbook of Sports Studies (pp. 477-489). London: SAGE Publications. 
Ellemers, N., Kingma, L., van de Burgt, J., \& Barreto, M. (2011). Corporate social responsibility as a source of organizational morality, employee commitment and satisfaction. Journal of Organizational Moral Psychology, 1(2), 97-124.

Fairley, S., Kellett, P., \& Green, B. C. (2007). Volunteering abroad: Motives for travel to volunteer at the Athens Olympic games. Journal of Sport Management, 21(1), 41-58.

Ferrin, D. L., Dirks, K. T., \& Shah, P. P. (2006). Direct and indirect effects of third-party relationships on interpersonal trust. Journal of Applied Psychology, 91(4), 870-883.

Filo, K., Funk, D. C., \& O'Brien, D. (2009). The meaning behind attachment: Exploring camaraderie, cause, and competency at a charity sport event. Journal of Sport Management, 23(3), 361-387.

Forest, J., Mageau, G. A., Sarrazin, C., \& Morin, E. M. (2011). "Work is my passion": the different affective, behavioural, and cognitive consequences of harmonious and obsessive passion toward work. Canadian Journal of Administrative Sciences, 28(1), 27-40.

Fornell, C., \& Larcker, D. (1981). Structural equation models with unobservable variables and measurement error. Journal of Marketing Research, 19(3), 382-388.

Frone, M. R., Russell, M., \& Cooper, M. L. (1995). Job stressors, job involvement and employee health: A test of identity theory. Journal of Occupational and Organizational Psychology, 68(1), 1-11.

Gouthier, M. H. J., \& Rhein, M. (2011). Organizational pride and its positive effects on employee behavior. Journal of Service Management, 22(5), 633-649.

Hair, J. F., Black, W. C., Babin, B. J., Anderson, R. E., \& Tatham, R. L. (2006). Multivariate Data Analysis (6th ed.). Upper Saddle River, NJ: Pearson Education. 
Ho, V. T., Wong, S. S., \& Lee, C. H. (2011). A tale of passion: Linking job passion and cognitive engagement to employee work performance. Journal of Management Studies, $48(1), 26-47$.

Hodgins, H. S., \& Knee, R. (2002). The integrating self and conscious experience. In E. L. Deci \& R. M. Ryan (Eds.), Handbook on self-determination research: Theoretical and applied issues (pp. 87-100). Rochester, NY: University of Rochester Press.

Horberg, E. J., Kraus, M. W., \& Keltner, D. (2013). Pride displays communicate self-interest and support for meritocracy. Journal of Personality aid Social Psychology, 105(1), 24-37.

Houlfort, N. L., Philippe, F. J., Vallerand, R. J., \& Ménard, J. (2014). On passion and heavy work investment: Personal and organizational outcomes. Journal of Managerial Psychology, 29(1), 25-45.

Hulland, J. (1999). Use of partial least squares (PLS) in strategic management research: A review of four recent studies. Strategic Management Journal, 20, 195-204.

Jiang, J. T., Klein, G., \& Carr, C. L. (2002). Measuring information system service quality: SERVQUAL from the other side. MIS Quarterly, 26(2), 145-166.

Jordan, J. S., Walker, M., Kent, A., \& Inoue, Y. (2011). The frequency of nonresponse analyses in the Journal of Sport Management. Journal of Sport Management, 25(3), 229-239.

Kanungo, R. N. (1982). Measurement of job and work involvement. Journal of Applied Psychology, 67(3), 341-349.

Katzenbach, J. R. (2003a). Pride: a strategic asset. Strategy \& Leadership, 31(5), 34-38.

Katzenbach, J. R. (2003b). Why pride matters more than money: the power of the world's greatest motivational force. New York: Crown Business. 
Kline, R. B. (2005). Principles and practice of structural equation modeling (2nd ed.). New York, NY: Guilford.

Lawler, E. E. (1992). The ultimate advantage: Creating the high-involvement organization. San Francisco, CA: Jossey-Bass.

Lee, K., \& Allen, N. J. (2002). Organizational citizenship behavior and workplace deviance: the role of affect and cognitions. Journal of Applied Psychology, 87(1), 131-142.

Leedy, D. L., \& Ormrod, J. E. (2001). Practical Research (7th ed.). Upper Saddle River, NJ: Prentice-Hall.

Locke, E. A. (1976). The nature and causes of job satisfaction. In M. D. Dunnette (Ed.), Handbook of industrial and organizational psychology (pp. 1297-1349). Chicago, IL: Rand McNally.

Maraniss, D. (1999). When pride still mattered: A life of Vince Lombardi. New York: Simon \& Schuster.

Marsh, H. W., Vallerand, R. J., Lafrenière, M. K., Parker, P., Morin, A. J., Carbonneau, N.,...Abduljabbar, A. S. (2013). Passion: Does One Scale Fit All? Construct Validity of Two-Factor Passion Scale and Psychometric Invariance Over Different Activities and Languages. Psychological Assessment, 25(3), 796-809.

Mazzeo, M., \& Youngmisuk, O. (2014, April 19). Masai Ujiri apologizes after rally. ESPN. Retrieved August 4, 2015, from http://abcnews.go.com/Sports/masai-ujiri-apologizesrally/story?id=23394799

Meyer, J. P., Allen, N. J., \& Smith, C. A. (1993). Commitment to organizations and occupations: Extension and test of a three-component conceptualization. Journal of Applied Psychology, 78(4), 538-551. 
808

809

810

811

812

813

814

815

816

817

818

819

820

821

822

824

825

826

827

828

829

Michael, R. (2008, November 24). Peyton Manning: the most passionate player in football. Bleacher Report. Retrieved August 4, 2015, from http:/http://bleacherreport.com/articles/85724-peyton-manning-the-most-passionateplayer-in-football

Misener, L., \& Mason, D. S. (2009). Fostering community development through sporting events strategies: An examination of urban regime perceptions. Journal of Sport Management, 23(6), $770-794$.

Muthén, L. K.., \& Muthén, B. O. (1998-2012). Mplus User's Guide (7th Ed.). Los Angeles, CA: Muthén \& Muthén.

Organ, D. W. (1988). Organizational citizenship behavior: the good soldier syndrome. Lexington, MA: Lexington Books.

Organ, D. W. (1990). The motivational basis of organizational citizenship behavior. In B. M. Staw \& L. L. Cummings (Eds.), Research in Organizational Behavior (Vol. 12, pp. 4372). Greenwich, CT: JAI.

Organ, D. W., \& Ryan, K. (1995). A meta-analytic review of attitudinal and dispositional predictors of organizational citizenship behavior. Personnel Psychology, 48(4), 775-802.

Paullay, I. M., Alliger, G. M., \& Stone-Romero, E. F. (1994). Construct validation of two instruments designed to measure job involvement and work centrality. Journal of Applied Psychology, 79(2), 224-228.

Philippe, F. L., Vallerand, R. J., Houlfort, N., Lavigne, G. L., \& Donahue, E. G. (2010). Passion for an activity and quality of interpersonal relationships: the mediating role of emotions. Journal of Personality and Social Psychology, 98(6), 917-932. 
Podsakoff, N. P., Whiting, S. W., Podsakoff, P. M., \& Blume, B. D. (2009). Individual- and organizational-level consequences of organizational citizenship behaviors: A metaanalysis. Journal of Applied Psychology, 94(1), 122-141.

Podsakoff, P. M., MacKenzie, S. B., Lee, J., \& Podsakoff, N. P. (2003). Common method biases in behavior research: A critical review of the literature and recommended remedies. Journal of Applied Psychology, 88(5), 879-903.

Pritchard, M. P., \& Funk, D. C. (2010). The formation and effect of attitude importance in professional sport. European Journal of Marketing, 44(7/8), 1017-1036.

Rich, B. L., Lepine, J. A., \& Crawford, E. R. (2010). Job engagement: Antecedents and effects on job performance. Academy of Management Journal, 53(3), 617-635.

Schleicher, D. J., Hansen, S. D., \& Fox, K. E. (2011). Job attitudes and work values. In S. Zedeck (Ed.), APA handbook of industrial and organizational psychology (Vol. 3, pp. 137-189). Washington, D.C.: American Psychological Association.

Sheldon, K. M. (2002). The self-concordance model of healthy goal-striving: When personal goals correctly represent the person. In E. L. Deci \& R. M. Ryan (Eds.), Handbook of Self-Determination Theory (pp. 65-86). Rochester, NY: University of Rochester Press.

Slack, T. (1996). From the locker room to the board room: Changing the domain of sport management. Journal of Sport Management, 10(1), 97-105.

Smith, H. J., \& Tyler, T. R. (1997). Choosing the right pond: the impact of group membership on self-esteem and group-oriented behavior. Journal of Experimental Social Psychology, $33(2), 146-170$.

Sokolowski, R. (2001). Friendship and moral action in Aristotle. The Journal of Value Inquiry, 35(3), 355-369. 
853

854

855

856

857

858

859

860

861

862

863

864

865

866

867

868

869

870

871

872

873

874

Stam, W., \& Elfring, T. (2008). Entrepreneurial orientation and new venture performance: the moderating role of intra-and extraindustry social capital. Academy of Management Journal, 51(1), 97-111.

Stewart, B., \& Smith, A. (1999). The special features of sport. Annals of Leisure Research, 2(1), 87-99.

Swanson, S., \& Kent, A. (2014). The complexity of leading in sport: Examining the role of domain expertise in assessing leader credibility and prototypicality. Journal of Sport Management, 28(1), 81-93.

Swanson, S., \& Kent, A. (2015). Fandom in the workplace: Multi-target identification in professional sports. Journal of Sport Management, 29(4), 461-477.

Tajfel, H. (1981). Human groups and social categories: Studies in social psychology. Cambridge, UK: Cambridge University Press.

Taylor, T., Doherty, A., \& McGraw, P. (2008). Managing people in sport organizations: A strategic human resource management perspective (1st ed.). New York, NY: Routledge.

Todd, S., \& Kent, A. (2009). A social identity perspective on the job attitudes of employees in sport. Management Decision, 47(1), 173-190.

Todd, S. Y., \& Harris, K. J. (2009). What it means when your work is admired by others: Observations of employees of professional sport organizations. Journal of Behavioral and Applied Management, 10(3), 396-414.

Trail, G. T., Robinson, M. J., Dick, R. J., \& Gillentine, A. J. (2003). Motives and points of attachment: Fans versus spectators in intercollegiate athletics. Sport Marketing Quarterly, 12(4), 217-227. 
875

876

877

878

879

880

881

882

883

884

885

886

887

888

889

890

891

892

893

894

895

896

Trepanier, S. G., Fernet, C., Austin, S., Forest, J., \& Vallerand, R. J. (2014). Linking job demands and resources to burnout and work engagement: Does passion underlie these differential relationships? Motivation and Emotion, 38(3), 353-366.

Tyler, T. R., \& Blader, S. L. (2001). Identity and cooperative behavior in groups. Group processes \& Intergroup Relations, 4(3), 207-226.

Vallerand, R. J. (1983). On emotion in sport: Theoretical and social psychological perspectives. Journal of Sport Psychology, 5(2), 197-215.

Vallerand, R. J. (2010). On passion for life activities: The dualistic model of passion. In M. P. Zanna (Ed.), Advances in experimental pyschology (Vol. 42, pp. 97-193).

Vallerand, R. J., \& Blanchard, C. M. (2000). The study of emotion in sport and exercise: Historical, definitional, and conceptual perspectives. In Y. L. Hanin (Ed.), Emotions in sport (pp. 3-37). Champaign, IL: Human Kinetics.

Vallerand, R. J., Blanchard, C., Mageau, G. A., Koestner, R., Ratelle, C., Leonard, M., \& Gagne, M. (2003). Les passions de l'ame: on obsessive and harmonious Passion. Journal of Personality and Social Psychology, 85(4), 756-767.

Vallerand, R. J., \& Houlfort, N. (2003). Passion at work: Toward a new conceptualization. In S. W. Gilliland, D. D. Steiner, \& D. P. Skarlicki (Eds.), Emerging perspectives on values in organizations (1st ed., Vol. 3, pp. 175-204). Greenwich, CT: Information Age Publishing.

Vallerand, R. J., Mageau, G. A., Elliot, A. J., Dumais, A., Demers, M. A., \& Rousseau, F. (2008a). Passion and performance attainment in sport. Psychology of Sport and Exercise, $9(3), 373-392$. 
897

898

899

900

901

902

903

904

905

906

907

908

909

910

911

912

913

914

915

916

917

918

Vallerand, R. J., Ntoumanis, N., Philippe, F. L., Lavigne, G. L., Carbonneau, N., Bonneville, A., Maliha, G. (2008b). On passion and sports fans: A look at football. Journal of Sports Sciences, 26(12), 1279-1293.

Vallerand, R. J., Paquet, Y., Philippe, F. L., \& Charest, J. (2010). On the role of passion for work in burnout: A process model. Journal of Personality, 78(1), 289-312.

Vallerand, R. J., Rousseau, F. L., Grouzet, F. M. E., Dumais, A., Grenier, S., \& Blanchard, C. M. (2006). Passion in sport: A look at determinants and affective experiences. Journal of Sport and Exercise Psychology, 28(4), 454-478.

Wann, D. L. (1997). Sport Psychology. Upper Saddle River, NJ: Prentice-Hall, Inc.

Wann, D. L., Dolan, T. J., McGeorge, K. K., \& Allison, J. A. (1994). Relationships between spectator identification and spectators' perceptions of influence, spectators' emotions, and competition outcome. Journal of Sport and Exercise Psychology, 16(4), 347-364.

Wann, D. L. (2006). The causes and consequences of sport team identification. In A. A. Raney \& J. Bryant (Eds.), Handbook of sports and media (pp. 331-352). Mahwah, NJ: Erlbaum

Wärnå, C., Lindholm, L., \& Eriksson, K. (2007). Virtue and health-finding meaning and joy in working life. Scandinavian Journal of Caring Sciences, 21(2), 191-198.

Weinberg, R. S., \& Gould, D. (2011). Foundations of sport and exercise psychology (5th ed.). Champaign, IL: Human Kinetics.

Weiss, H. M. (2002). Deconstructing job satisfaction: Separating evaluations, beliefs and affective experiences. Human Resource Management Review, 12(2), 172-194.

Zinser, L. (2005, April 3). Summitt's intensity stokes Tennessee's fire. New York Times. Retrieved August 4, 2015, from 

http:/http://www.nytimes.com/2005/04/03/sports/sportsspecial/summitts-intensitystokes-tennessees-fire.html? $\mathrm{r}=0$ 

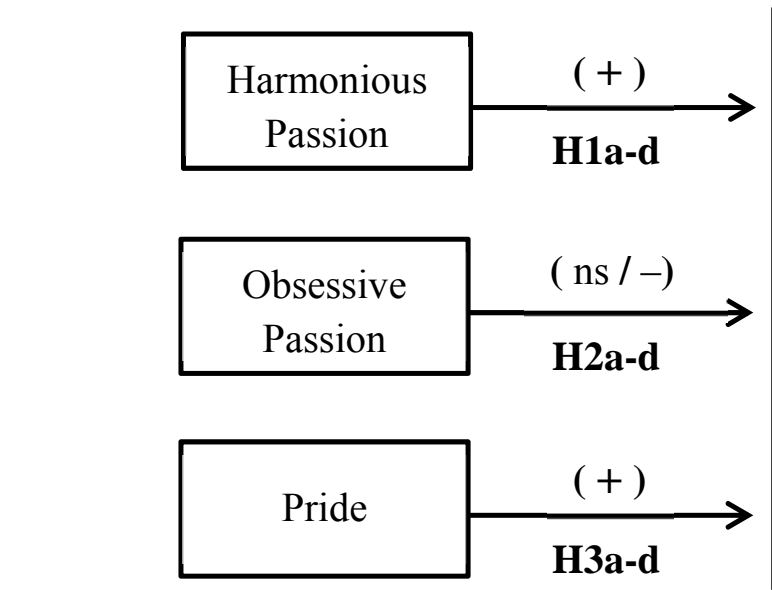

\section{Attitudes}

Affective Commitment

Job Satisfaction

Job Involvement

\section{Behaviors}

Organizational

Citizenship Behavior
931

932

933

934

935

936

937

Table 1. Correlation matrix of the constructs

\begin{tabular}{|c|c|c|c|c|c|c|c|c|c|}
\hline & $\alpha$ & $\mathrm{CR}$ & AVE & 1 & 2 & 3 & 4 & 5 & 6 \\
\hline 1. Obsessive passion & .80 & .80 & .57 & 1.00 & & & & & \\
\hline 2. Job pride & .89 & .89 & .74 & .41 & 1.00 & & & & \\
\hline 3. Affective commitment & .85 & .85 & .49 & .39 & .34 & 1.00 & & & \\
\hline 4. Job satisfaction & .85 & .93 & .66 & .32 & .28 & .79 & 1.00 & & \\
\hline 5. Job involvement & .88 & .88 & .61 & .79 & .43 & .50 & .41 & 1.00 & \\
\hline 6. $\mathrm{OCB}$ & .77 & .78 & .54 & .20 & .27 & .34 & .31 & .22 & 1.00 \\
\hline
\end{tabular}

All values significant $(p<.001) ; \alpha=$ Cronbach alpha

Figure 1. A model of affective influence on organizational outcomes in professional team sport organizations 
Table 2. Structural Model Comparisons

\begin{tabular}{cccccccc}
\hline & $\chi^{2}$ & $d f$ & CFI & TLI & RMSEA & SRMR & AIC \\
\hline Model 1 & 870 & 234 & .93 & .92 & .05 & .04 & 55868 \\
Model 2 & 979 & 257 & .92 & .91 & .06 & .05 & 61857 \\
Model 3 & 1419 & 263 & .88 & .86 & .07 & .09 & 62341 \\
\hline
\end{tabular}

944

945

946

947

948

949

950

951

952

953

954

955

956

957

958

959

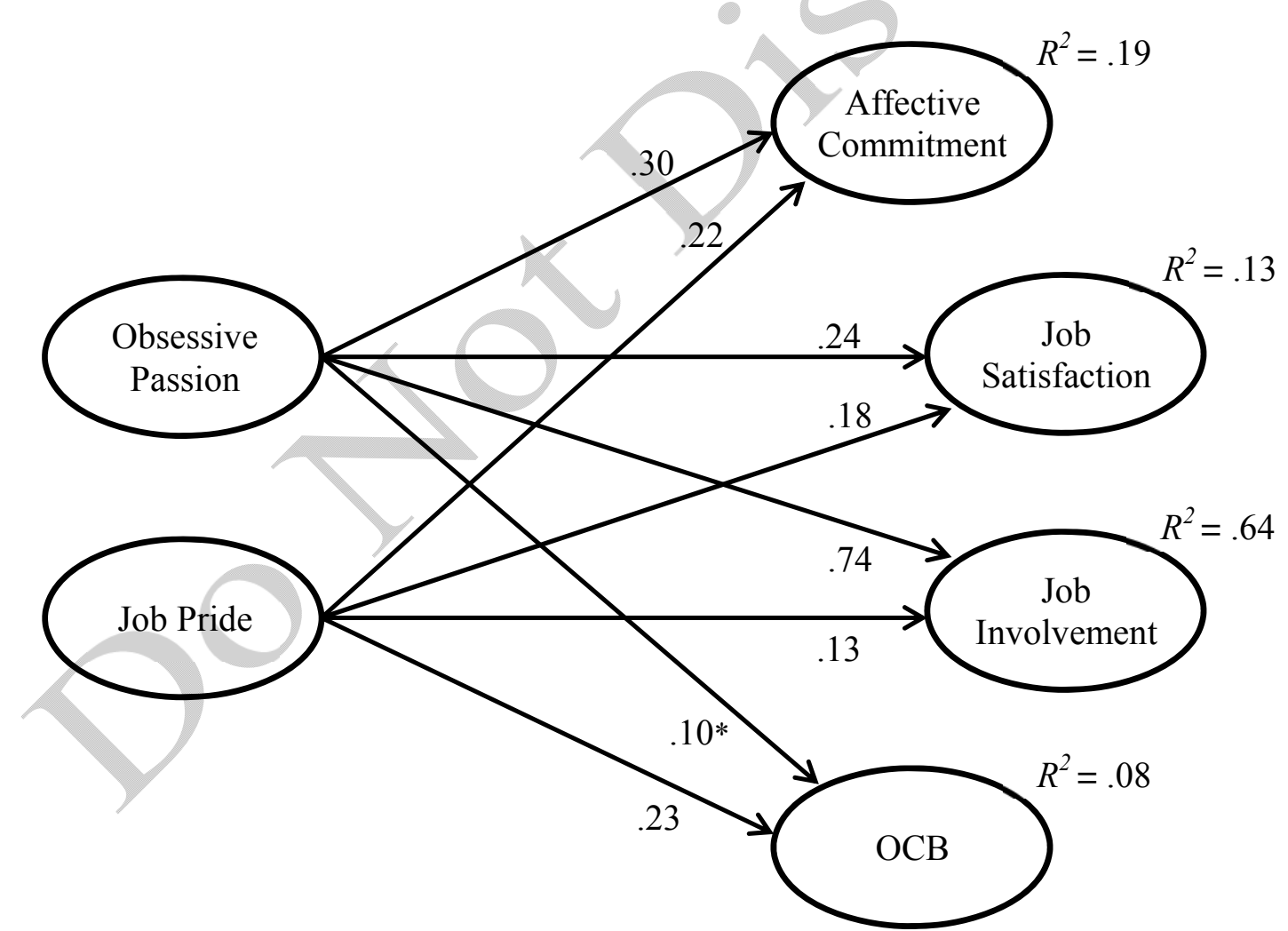

960

Figure 2. Final Structural Model Note. All parameter estimates significant at $p<.001$, unless otherwise 961 indicated $\left({ }^{*} p<.05\right)$. 